\title{
Disrespectful and abusive maternity care during childbirth in Bale zone Public Hospitals, southeast Ethiopia: Cross- sectional study
}

\begin{abstract}
Background: Disrespectful and abusive maternity care is an indicator of poor quality care affecting women's decision to pursue institutional delivery. In spite of severe burdens, such malpractices remain hidden and are infrequently stated in developing countries. Therefore, this study aims to assess the status of disrespectful and abusive maternity care during childbirth and associated factors among postnatal women in public hospitals of Bale zone, Southeast Ethiopia.

Method: An institutional-based cross-sectional study was done from March, 1 to July 25, 2018, among 580 postnatal women in three public hospitals of Bale zone using exit interview. Epi info for data entry and SPSS for analyzing were used. To examine the association between outcome and independent variables adjusted odds ratio with a $95 \%$ confidence interval and $p$-value $<0.05$ were used.

Result: The status of disrespectful and abusive maternity care is $37.5 \%$. In the association result, the significantly associated factors with disrespectful and abusive maternity care are; marital status with married women are $82 \%$ less likely to get disrespectful and abusive maternity care than their counterpart ( $\mathrm{AOR}=0.18, \mathrm{Cl}: 0.04-0.78$ ). secondly, women who do not have antenatal care follow-up history are 8.62 times more likely to encounter disrespectful and abuse maternity care compared to those who had (AOR=8.62;95\% Cl: 1.73-43.08). Those verbally threatened women had higher odds of experiencing disrespectful and abusive maternity care than who do not (AOR=3.68; $95 \% \mathrm{Cl}: 1.45-9.36)$. Furthermore, women who ever physically abused are 5.80 times more likely to experience disrespectful and abusive maternity care compared to who do not (AOR=5.80: $95 \% \mathrm{Cl}: 2.77-12.16)$. Provision of respectful maternity care training for care providers is important.
\end{abstract}

\section{Keywords: disrespectful, abusive, threatened, women, compassionate, respectful}

\section{Abbreviations}

ANC: Antenatal Care; D and A: Disrespectful and Abusive; MMR: Maternal Mortality Rate; RMC: Respectful Maternity Care; SPSS: Statistical Package for Social Science; AOR: Adjusted Odds Ratio; OR: Odds Ratio

\section{Background}

Disrespectful and abusive (D and A) maternity care is not only a deviation from health rights, but it also includes situations experienced as humiliating or undignified interactions from individual, structural, and policy perspectives [1-3]. The Federation of Women Lawyers and the Centre for Reproductive Rights in 2007 defined D and A maternity care as physical abuse, verbal abuse, non-dignified care, non-consented care, discrimination, abandonment of women and detention in a facility because of inability to pay [4].

$\mathrm{D}$ and A maternity care during childbirth in Ghana were experienced by $98 \%$ of women [5] and 20\% in Kenya [6]. Likewise, D and A prevalence in an Addis Ababa health facility was 78\% [7] but in public health facilities of Ethiopia was 36\% [8]. Because of the prominence of $\mathrm{D}$ and $\mathrm{A}$ in Ethiopia, only $26 \%$ of women give birth in the health facility and maternal mortality rate (MMR) accounts 412 deaths per 100,000 live births [9]. Low monthly income, obtaining care from midwives, having a male health care provider, having a birth companion [8], being young age women [6], high educational level, post-traumatic stress and physical complaints are factors significantly associated with $\mathrm{D}$ and

\section{Ashenafi Mekonnen ${ }^{1 *}$, Genet Fikadu ${ }^{1}$ and Adem Esmeal $^{2}$}

${ }^{1}$ Department of Midwifery, School of Health Science, Goba Referral Hospital, Madda Walabu University, Bale Goba, Ethiopia

${ }^{2}$ Department of Nursing, School of Health Science, Goba Referral Hospital, Madda Walabu University, Bale Goba, Ethiopia

*Author for correspondence:

ashemw@gmail.com 
A [10].

So far, efforts have been made to reduce the high MMR by increasing the proportion of institutional delivery. These efforts will be achieved to some degree by providing respectful and non-abusive maternity care [11]. Therefore, this study aimed to assess the prevalence of disrespectful and abusive maternity care during childbirth and associated factors among postnatal women in public hospitals of Bale Zone, southeast Ethiopia.

\section{Method}

\section{- Study area and period}

The study was conducted in Bale zone hospitals. Bale zone is located in South-East Ethiopia. Robe, the Zonal city, is located 435 $\mathrm{km}$ far from the capital town of Ethiopia; Addis Ababa. Based on the 2007 national census Bale Zone has a total population of 1,402,492; of whom 713,517 are men (CSA, 2007). The Zone has 715 health facilities: 1 referral hospital, 4 hospitals, 84 health centers, 354 functional health post, 179 private clinics, 4 other public clinics, 95 pharmacy/drug shop, and 4 medical drug store. The study was conducted at Goba Referral Hospital, Ginnir Hospital and Delo Mena Hospital from March, 1 to July 25, 2018.

\section{- Study design}

The cross-sectional survey was conducted.

\section{Source and study population}

All postnatal women who give birth at 3 public hospitals in the Bale Zone were considered as source population. Whereas all postnatal women who give birth to 3 public hospitals in Bale Zone during the data collection period were considered as the study population.

\section{Sample size determination and sampling procedure}

To determine the sample size a single population proportion formula was used with the assumptions of the prevalence of $\mathrm{D}$ and A care in Addis Ababa is 78\% [7], a 5\% margin of error, a $95 \% \mathrm{CI}$ and a design effect of 2 . Then by adding a $10 \%$ of non-response rate, the final sample size is 580 . Multistage sampling was used to select study subjects.
Goba, Delomena and Ginnir hospitals were selected using a lottery method out of the 5 hospitals in the zone. The sample was allocated proportionally to the three hospitals based on the annual frequency of deliveries. To select the study subjects, a systematic random sampling of every $2^{\text {nd }}$ case was used and the lottery method was used to select the first mother.

\section{Data collection tools and data quality control}

After reviewing the literature, a structured questionnaire addressing socio-economic, obstetric and maternal health service use history and past experience was developed. In addition, we have used Bowser and Hill's framework to assess D and A, which identifies seven categories of concern. These categories are physical abuse, non-consented care, non-confidential care, non-dignified care, discrimination of patients, abandonment of care and detention in facilities [1]. The questions were initially written in the English language and then translated to Amharic and Afan Oromo language by another person. Furthermore, the questionnaire was retranslated back to English by another translator to compare for consistency. A structured Amharic and Afan Oromo version questionnaire were used after pre-testing on $10 \%$ of the same source population other than the sampled population. During the actual data collection process, supervisors have cross-checked the data collectors in the field randomly every day for questionnaire consistency and completeness. Completed questionnaires were checked daily. Because of the sensitivity of these issues, during data collection, the exit interview was administered in a private setting.

\section{- Inclusion and exclusion criteria}

All postnatal women who give birth at the 3 study public hospitals were included whereas women who didn't give birth at the 3 study public hospitals but attended postnatal services at them were excluded from the study.

\section{Study Variables}

$\mathrm{D}$ and $\mathrm{A}$ maternity care during childbirth was the independent variable and the sociodemographic factors: economic status, occupation, educational status, age, and 
marital status. Past obstetric history: parity, presence of significant others, childbirth experience, perceived quality of care received and time of delivery. Health facility factor: the profession of care provider and sex of care provider.

\section{Data processing and analysis}

Epi info version 7 was used to enter the collected data and then exported for analysis to Statistical Package for Social Science (SPSS) version 21 . To determine the status of $D$ and A we have transformed the seven categories of Bowser's model into a dichotomous variable. Incomplete questionnaires were excluded from analysis and considered to be a nonresponse. After running descriptive analysis, the results were presented using frequency, mean, standard deviation and tables. Furthermore, to examine the association between dependent and independent variables binary logistic regression analysis was carried out. Therefore, those variables with $\mathrm{p}$-value $<0.2$ in the bivariate analysis were entered into a multivariable logistic regression model to identify the significant factors associated with D and A. AOR with $95 \% \mathrm{CI}$ and $\mathrm{p}$-value $<0.05$ were used to examine the association between the independent and dependent variables.

\section{- Operational definition}

Disrespectful and abusive maternity care during childbirth: Physical abuse, nonconsented clinical care, non-confidential care, non-dignified care (including verbal abuse), discrimination of patients, abandonment of care, and detention in facilities by health care professionals during childbirth.

\section{Ethical Consideration}

We have submitted an ethical clearance letter to respective hospitals after obtaining ethical clearance from the ethical review board of Madda Walabu University. Then, the hospitals wrote a letter of permission for the maternity unit. Finally, we have secured informed verbal consent from women.

\section{Results}

Five hundred and sixty-five (565) women completed the interview for a response rate of $97.4 \%$

\section{Socio-demographic factors}

From the total of 565 study participants, $451(79.8 \%)$ of the participants were between 20-34 years of age, with the mean age of 25.2 $( \pm 5.5)$. Three hundred and forty $(60 \%)$ are Oromo ethnic group and $202(35.8 \%)$ are Muslim in religion) (TABLE 1).

\section{Obstetric and maternal health} service use history and experience

Out of 565 study participants, 311 (55.0\%) had 2-4 children alive; 510 (90.7\%) of women had Antenatal Care (ANC) follow up for the current pregnancy and 303 (53.6\%) women had the previous history of institutional delivery (TABLE 2).

\section{- Past psychiatric experience}

From the 565 interviewed postnatal women $68(12 \%)$ reported that they had depression in the last 12 months and 62 (11\%) women were verbally threatened (TABLE 3).

Status of Disrespectful and abusive maternity care

About 124 (60.5\%), 32 (28.1\%) and 56 $(22.8 \%)$ women were encountered D and $A$ at Ginnir, Delomena and Goba hospital respectively making the overall status of $D$ and A maternity care during childbirth in Bale Zone public hospitals as 37.5\%.

\section{- Factors associated with disrespectful and abusive maternity care}

In bivariate analysis the factors found to be significantly associated with $\mathrm{D}$ and A maternity care were: age of respondents, marital status, duration of travel, residency area, history of ANC, sex of care providers, any birth complication encountered, delivery place preference, reported depression mood, ever verbally threatened and ever physically abused. However, the following variables were significantly associated with D and A maternity care in the multivariate; Married women had $82 \%$ less likely to encounter $\mathrm{D}$ and $\mathrm{A}$ maternity care than single women (AOR=0.18; 95\% CI: 0.04-0.78). Women who do not have ANC follow-up history are 8.62 times more likely to encounter D and A maternity care during childbirth compared to those who had $(\mathrm{AOR}=8.62 ; 95 \% \mathrm{CI}$ : $1.73-$ 43.08). Those verbally threatened women 


\begin{tabular}{|c|c|c|}
\hline Variables & Frequency & Percentage (\%) \\
\hline $\begin{array}{l}\text { Age of respondents } \\
<20 \text { years } \\
20-34 \text { years } \\
>34 \text { years }\end{array}$ & $\begin{array}{l}73 \\
451 \\
41\end{array}$ & $\begin{array}{l}12.9 \\
79.8 \\
7.3\end{array}$ \\
\hline $\begin{array}{l}\text { Marital status of woman } \\
\text { Married } \\
\text { Single/divorced/widowed }\end{array}$ & $\begin{array}{l}533 \\
32\end{array}$ & $\begin{array}{l}94.3 \\
5.7\end{array}$ \\
\hline $\begin{array}{l}\text { Ethnicity } \\
\text { Oromo } \\
\text { Amhara } \\
\text { Others }^{\circledast}\end{array}$ & $\begin{array}{l}340 \\
163 \\
62\end{array}$ & $\begin{array}{l}60.2 \\
28.8 \\
11.0\end{array}$ \\
\hline $\begin{array}{l}\text { Religion of respondents } \\
\text { Muslim } \\
\text { Orthodox } \\
\text { Protestant }\end{array}$ & $\begin{array}{l}279 \\
212 \\
74\end{array}$ & $\begin{array}{l}49.4 \\
37.5 \\
13.1\end{array}$ \\
\hline $\begin{array}{l}\text { Educational status } \\
\text { No formal education } \\
\text { Primary school } \\
\text { Secondary school } \\
\text { More than secondary school }\end{array}$ & $\begin{array}{l}152 \\
202 \\
143 \\
68 \\
\end{array}$ & $\begin{array}{l}26.9 \\
35.8 \\
25.3 \\
12.0 \\
\end{array}$ \\
\hline $\begin{array}{l}\text { Occupational status } \\
\text { Merchant } \\
\text { Employee } \\
\text { Housewife } \\
\text { Others }{ }^{\circledR} \\
\end{array}$ & $\begin{array}{l}106 \\
59 \\
383 \\
17\end{array}$ & $\begin{array}{l}18.8 \\
10.4 \\
67.8 \\
3.0\end{array}$ \\
\hline $\begin{array}{l}\text { Residency } \\
\text { Rural } \\
\text { Urban }\end{array}$ & $\begin{array}{l}241 \\
324\end{array}$ & $\begin{array}{l}42.7 \\
57.3\end{array}$ \\
\hline $\begin{array}{l}\text { Monthly income } \\
\text { Low } \\
\text { Middle } \\
\text { High }\end{array}$ & $\begin{array}{l}209 \\
350 \\
6\end{array}$ & $\begin{array}{l}37.0 \\
61.9 \\
1.1\end{array}$ \\
\hline $\begin{array}{l}\text { Means of transportation } \\
\text { On foot } \\
\text { By car } \\
\text { By cart }\end{array}$ & $\begin{array}{l}83 \\
437 \\
45\end{array}$ & $\begin{array}{l}14.7 \\
77.3 \\
8.0\end{array}$ \\
\hline $\begin{array}{l}\text { Time to travel hospital } \\
\leq 30 \text { minute } \\
>30 \text { minute }\end{array}$ & $\begin{array}{l}332 \\
233\end{array}$ & $\begin{array}{l}58.8 \\
41.2\end{array}$ \\
\hline $\begin{array}{l}\text { The HIV status of respondents } \\
\text { Positive } \\
\text { Negative }\end{array}$ & $\begin{array}{l}15 \\
550\end{array}$ & $\begin{array}{l}2.7 \\
97.3\end{array}$ \\
\hline Note: Others ${ }^{\oplus}$ :Tigrie, Wolayita & & \\
\hline
\end{tabular}

had higher odds of experiencing $\mathrm{D}$ and $\mathrm{A}$ maternity care than who do not $(\mathrm{AOR}=3.68$; 95\% CI: 1.45-9.36). Women who were ever physically abused are 5.80 times more likely to experience $\mathrm{D}$ and $\mathrm{A}$ maternity care compared to who do not $(\mathrm{AOR}=5.80: 95 \% \mathrm{CI}: 2.77$ 12.16) (TABLE 4).

\section{Discussion}

This study aimed to assess the status of D and A maternity care and associated factors among postnatal women in public hospitals of Bale Zone, southeast Ethiopia. In this study, the overall status of D and A maternity care is found to be $37.5 \%$ (95\% CI: $33.5 \%$, $41.0 \%)$. This finding is higher than the studies conducted in Tanzania 19.5\% [12], Kenya $20 \%$ [6], and District of Gujrat 27.2\% [13]. The possible explanation for this variation could be because of high workload and low job satisfaction. However; it is lower than the studies done in Ghana 98\% [5], Southwest Nigeria 93.2\% [14], Addis Ababa 78\% [7] and Bahir Dar 67.1\% [15]. This discrepancy could be attributed by the presence of on job training on Respectful Maternity Care (RMC).

The odds of experiencing $\mathrm{D}$ and $\mathrm{A}$ 


\begin{tabular}{|c|c|c|}
\hline variables & Frequency & Percentile (\%) \\
\hline $\begin{array}{l}\text { Number of living children } \\
\text { One child } \\
2-4 \text { children's } \\
\geq 5 \text { children's }\end{array}$ & $\begin{array}{l}186 \\
311 \\
68\end{array}$ & $\begin{array}{l}32.9 \\
55.0 \\
12.0\end{array}$ \\
\hline $\begin{array}{l}\text { History of ANC use for current pregnancy } \\
\text { Yes } \\
\text { No }\end{array}$ & $\begin{array}{l}510 \\
55\end{array}$ & $\begin{array}{l}90.7 \\
9.7\end{array}$ \\
\hline $\begin{array}{l}\text { Number of ANC visit } \\
\text { First visit } \\
\text { Second visit } \\
\text { Third visit } \\
\text { Fourth visit } \\
\text { More than four visit }\end{array}$ & $\begin{array}{l}15 \\
35 \\
128 \\
204 \\
128\end{array}$ & $\begin{array}{l}2.9 \\
6.9 \\
25.1 \\
40.0 \\
25.1 \\
\end{array}$ \\
\hline $\begin{array}{l}\text { History of previous institutional delivery } \\
\text { Yes } \\
\text { No }\end{array}$ & $\begin{array}{l}303 \\
262\end{array}$ & $\begin{array}{l}53.6 \\
46.4 \\
\end{array}$ \\
\hline $\begin{array}{l}\text { Previous delivery in the current facility } \\
\text { Yes } \\
\text { No }\end{array}$ & $\begin{array}{l}183 \\
120\end{array}$ & $\begin{array}{l}60.4 \\
39.6\end{array}$ \\
\hline $\begin{array}{l}\text { Time of delivery } \\
\text { Day } \\
\text { Night } \\
\end{array}$ & $\begin{array}{l}121 \\
182 \\
\end{array}$ & $\begin{array}{l}39.9 \\
60.1\end{array}$ \\
\hline $\begin{array}{l}\text { Number of care providers } \\
\text { One } \\
\text { Two } \\
\text { Three-four } \\
\text { Five and above }\end{array}$ & $\begin{array}{l}31 \\
244 \\
245 \\
45\end{array}$ & $\begin{array}{l}5.5 \\
43.2 \\
43.4 \\
8.0\end{array}$ \\
\hline $\begin{array}{l}\text { Sex of care provider } \\
\text { Male } \\
\text { Female }\end{array}$ & $\begin{array}{l}360 \\
205\end{array}$ & \begin{tabular}{|l|}
63.7 \\
36.3
\end{tabular} \\
\hline $\begin{array}{l}\text { Birth complication } \\
\text { Yes } \\
\text { No } \\
\text { I don't know }\end{array}$ & $\begin{array}{l}113 \\
423 \\
29\end{array}$ & $\begin{array}{l}20.0 \\
74.9 \\
5.1\end{array}$ \\
\hline $\begin{array}{l}\text { Presence of friends/family } \\
\text { No support } \\
\text { Supported by a family/friend }\end{array}$ & \begin{tabular}{|l}
22 \\
543 \\
\end{tabular} & $\begin{array}{l}3.9 \\
96.1\end{array}$ \\
\hline $\begin{array}{l}\text { Delivery place preference } \\
\text { Health center } \\
\text { Hospital Health post } \\
\text { Home }\end{array}$ & $\begin{array}{l}43 \\
479 \\
43\end{array}$ & $\begin{array}{l}7.6 \\
84.8 \\
7.6\end{array}$ \\
\hline $\begin{array}{l}\text { Any payment during delivery } \\
\text { Yes } \\
\text { No }\end{array}$ & $\begin{array}{l}2 \\
563 \\
\end{array}$ & 99.6 \\
\hline $\begin{array}{l}\text { Did they ordered you to buy glove or drug } \\
\text { Yes } \\
\text { No }\end{array}$ & \begin{tabular}{|l}
10 \\
555
\end{tabular} & \begin{tabular}{|l}
1.8 \\
98.2
\end{tabular} \\
\hline $\begin{array}{l}\text { Recommended to visit private clinic } \\
\text { Yes } \\
\text { No }\end{array}$ & $\begin{array}{l}5 \\
560\end{array}$ & $\begin{array}{l}0.9 \\
99.1\end{array}$ \\
\hline
\end{tabular}

maternity care among married women was $82 \%$ less likely than single women. This finding is consistent with the study done in Kenyatta National Hospital [16]. This similarity could be attributed by the presence of similar socio-economic status and used the same tool to assess D and A maternity care.
Women who do not have ANC followup history are 8.62 times more likely to experience $\mathrm{D}$ and $\mathrm{A}$ maternity care compared to those who had. This finding supports the study conducted in Bahir Dar town revealing that those women who attended fewer ANC visits were experiencing $\mathrm{D}$ and A maternity care [15]. 


\begin{tabular}{|c|c|c|}
\hline Variables & Frequency & Percentage (\%) \\
\hline $\begin{array}{l}\text { The reported low mood within the last } 12 \text { months } \\
\text { Yes } \\
\text { No }\end{array}$ & \begin{tabular}{|l}
68 \\
497
\end{tabular} & $\begin{array}{l}12.0 \\
88.0\end{array}$ \\
\hline $\begin{array}{l}\text { Verbally threatened or humiliated } \\
\text { Yes } \\
\text { No }\end{array}$ & \begin{tabular}{|l}
62 \\
503
\end{tabular} & $\begin{array}{l}11.0 \\
89.0\end{array}$ \\
\hline $\begin{array}{l}\text { Ever been physically abused in your life } \\
\text { Yes } \\
\text { No }\end{array}$ & $\begin{array}{l}98 \\
467\end{array}$ & $\begin{array}{l}17.3 \\
82.7\end{array}$ \\
\hline $\begin{array}{l}\text { Ever been raped } \\
\text { Yes } \\
\text { No }\end{array}$ & $\begin{array}{l}10 \\
555\end{array}$ & \begin{tabular}{|l}
1.8 \\
98.2
\end{tabular} \\
\hline $\begin{array}{l}\text { Plan to use family planning } \\
\text { Yes } \\
\text { No }\end{array}$ & $\begin{array}{l}407 \\
158\end{array}$ & $\begin{array}{l}72.0 \\
28.0\end{array}$ \\
\hline
\end{tabular}

TABLE 4. Bivariable and Multivariable logistic regression analysis of factors associated with disrespectful and abusive maternity care during childbirth in public hospitals of Bale zone, Oromia regional state, Southeast Ethiopia, 2018 ( $n=565$ ).

\begin{tabular}{|c|c|c|c|c|}
\hline \multirow[t]{2}{*}{ Variables } & \multicolumn{2}{|c|}{$\begin{array}{l}\text { Disrespectful and } \\
\text { abusive }\end{array}$} & \multirow[t]{2}{*}{ Crude OR with $95 \% \mathrm{Cl}$} & \multirow[t]{2}{*}{ Adjusted OR with $95 \% \mathrm{Cl}$} \\
\hline & Yes & No & & \\
\hline $\begin{array}{l}\text { Age of respondent } \\
<20 \text { years } \\
20-34 \text { years } \\
>34 \text { years } \\
\end{array}$ & $\begin{array}{l}20 \\
170 \\
22\end{array}$ & $\begin{array}{l}53 \\
281 \\
19\end{array}$ & $\begin{array}{l}0.33(0.15-0.73) \\
0.62(0.28-0.99) \\
1.00\end{array}$ & $\begin{array}{l}0.38(0.03-4.30) \\
0.55(023-1.34) \\
1.00\end{array}$ \\
\hline $\begin{array}{l}\text { Marital status } \\
\text { Married } \\
\text { Single/widowed/divorced }\end{array}$ & $\begin{array}{l}194 \\
18\end{array}$ & $\begin{array}{l}339 \\
14\end{array}$ & $\begin{array}{l}0.45(0.22-0.92) \\
1.00\end{array}$ & $\begin{array}{l}\mathbf{0 . 1 8}(\mathbf{0 . 6 4 - 0 . 7 8 ) *} \\
1.00\end{array}$ \\
\hline $\begin{array}{l}\text { Travel duration } \\
\leq 30 \text { minutes } \\
>30 \text { minutes }\end{array}$ & $\begin{array}{l}107 \\
105\end{array}$ & $\begin{array}{l}225 \\
128\end{array}$ & $\begin{array}{l}0.58(0.41-0.82) \\
1.00\end{array}$ & $\begin{array}{l}0.97(0.48-1.95) \\
1.00\end{array}$ \\
\hline $\begin{array}{l}\text { Residency area } \\
\text { Rural } \\
\text { Urban }\end{array}$ & $\begin{array}{l}109 \\
103\end{array}$ & $\begin{array}{l}132 \\
221\end{array}$ & $\begin{array}{l}1.77(1.26-2.50) \\
1.00\end{array}$ & $\begin{array}{l}1.05(0.58-1.92) \\
1.00\end{array}$ \\
\hline $\begin{array}{l}\text { History of ANC } \\
\text { Yes } \\
\text { No } \\
\end{array}$ & $\begin{array}{l}177 \\
35\end{array}$ & $\begin{array}{l}333 \\
20\end{array}$ & $\begin{array}{l}1.00 \\
3.29(1.85-5.87)\end{array}$ & $\begin{array}{l}1.00 \\
8.62(1.73-43.08)^{* *}\end{array}$ \\
\hline $\begin{array}{l}\text { Sex of provider } \\
\text { Male } \\
\text { Female }\end{array}$ & $\begin{array}{l}128 \\
84\end{array}$ & $\begin{array}{l}232 \\
121\end{array}$ & $\begin{array}{l}0.80(0.56-1.13) \\
1.00\end{array}$ & $\begin{array}{l}1.20(0.68-2.12) \\
1.00\end{array}$ \\
\hline $\begin{array}{l}\text { Any birth complication } \\
\text { Yes } \\
\text { No } \\
\text { I don't know }\end{array}$ & $\begin{array}{l}58 \\
146 \\
8\end{array}$ & $\begin{array}{l}55 \\
277 \\
21\end{array}$ & $\begin{array}{l}1.00 \\
0.50(0.33-0.76) \\
0.36(0.15-0.88)\end{array}$ & $\begin{array}{l}1.00 \\
0.51(0.27-1.98) \\
0.23(0.05-1.03)\end{array}$ \\
\hline $\begin{array}{l}\text { Delivery place preference } \\
\text { Health center } \\
\text { Hospital } \\
\text { Home }\end{array}$ & $\begin{array}{l}18 \\
166 \\
28\end{array}$ & $\begin{array}{l}25 \\
313 \\
15\end{array}$ & $\begin{array}{l}1.00 \\
0.74(0.39-1.39) \\
2.59(1.08-6.20)\end{array}$ & $\begin{array}{l}1.00 \\
1.63(0.94-2.84 \\
1.13(0.56-1.92)\end{array}$ \\
\hline $\begin{array}{l}\text { Reported depression mood } \\
\text { Yes } \\
\text { No }\end{array}$ & $\begin{array}{l}43 \\
169\end{array}$ & $\begin{array}{l}25 \\
328\end{array}$ & $\begin{array}{l}3.34(1.97-5.65) \\
1.00\end{array}$ & $\begin{array}{l}2.01(0.79-5.14) \\
1.00\end{array}$ \\
\hline $\begin{array}{l}\text { Ever verbally threatened } \\
\text { Yes } \\
\text { No }\end{array}$ & $\begin{array}{l}42 \\
170\end{array}$ & $\begin{array}{l}20 \\
333\end{array}$ & $\begin{array}{l}4.11(2.34-7.23) \\
1.00\end{array}$ & $\begin{array}{l}3.68(1.45-9.36)^{* *} \\
1.00\end{array}$ \\
\hline $\begin{array}{l}\text { Ever physically abused } \\
\text { Yes } \\
\text { No }\end{array}$ & $\begin{array}{l}65 \\
147\end{array}$ & $\begin{array}{l}33 \\
320\end{array}$ & $\begin{array}{l}4.29(2.70-6.81) \\
1.00\end{array}$ & $\begin{array}{l}5.80(2.77-12.16)^{* *} \\
1.00\end{array}$ \\
\hline
\end{tabular}

Those verbally threatened or humiliated D and A maternity care than who do not. women had higher odds of experiencing Women who ever physically abused are 
5.80 times more likely to experience $\mathrm{D}$ and A maternity care compared to who do not. This finding supports the study conducted in 2011 indicating that women who experienced childhood abuse, presence of post-traumatic stress disorder and the presence of physical complaints were significantly associated with $\mathrm{D}$ and A maternity care [10].

\section{Conclusion}

The overall status of D and A maternity care during childbirth in public hospitals of Bale Zone was high. Being an unmarried woman, not having a history of ANC followup, being verbally threatened within the past 12 months and ever physically abused were significantly associated with the status of D and A maternity care during childbirth. The Bale Zone health office in collaboration with stakeholders has to provide RMC training for obstetrics care providers, increase ANC coverage through health education and mitigate domestic violence by empowering women.

\section{Competing Interests}

The authors declare that they have no competing interests.

\section{Acknowledgment}

We would like to express our warmest gratitude to Madda Walabu University for funding this research project. We would also like to extend our deepest appreciation to the three hospitals for providing permission to conduct this survey. Finally, we would like to acknowledge our study participants for providing us with important information.

\section{Authors' Contributions}

AMW, GFH, and AER designed the study and were involved in drafting, statistical analysis and correcting the manuscript. All the authors read the manuscript, critically revised it for important intellectual content and approved the final version of the manuscript. 


\section{References}

Bowser D, Hill K. Exploring the evidence for disrespect and abuse in facility-based childbirth. Boston: USAIDTRAction Project, Harvard School of Public Health. (2010).

Freedman LP, Ramsey K, Abuya T, et al. Defining disrespect and abuse of women in childbirth: a research, policy and rights agenda. Bull World Health Organ. 92(12), 915-917 (2014).

Rosen HE, Lynam PF, Carr C, et al. Direct observation of respectful maternity care in five countries: a cross-sectional study of health facilities in East and Southern Africa. BMC Pregnancy and Childbirth. 15(1), 306 (2015).

Rights CFR, Lawyers-Kenya FoW. Failure to deliver: Violations of women's human rights in Kenyan health facilities. CRR: FIDA-Kenya New York, Nairobi. (2007).

Okafor II, Ugwu EO, Obi SN. Disrespect and abuse during facility-based childbirth in a low-income country. Int. J. Gynaecol. Obstet. 128(2), 110-113 (2015).

Abuya T, Warren CE, Miller N, et al.
Exploring the prevalence of disrespect and abuse during childbirth in Kenya. PloS One. 10(4), e0123606 (2015).

Asefa A, Bekele D. Status of respectful and non-abusive care during facility-based childbirth in a hospital and health centers in Addis Ababa, Ethiopia. Reprod. Health. 12, 33 (2015).

Sheferaw ED, Bazant E, Gibson H, et al. Respectful maternity care in Ethiopian public health facilities. Reprod. Health. 14(1), 60 (2017).

https://dhsprogram.com/pubs/pdf/ FR328/FR328.pdf

Swahnberg K, Schei B, Hilden M, et al. Patients' experiences of abuse in health care: A Nordic study on prevalence and associated factors in gynecological patients Acta Obstet. Gynecol. Scand. 86(3), 349356 (2007).

Warren C, Njuki R, Abuya T, et al. Study protocol for promoting respectful maternity care initiative to assess, measure and design interventions to reduce disrespect and abuse during childbirth in Kenya. BMC Pregnancy and Childbirth. 13(1), 21 (2013).

Kruk ME, Kujawski S, Mbaruku
G. Disrespectful and abusive treatment during facility delivery in Tanzania: A facility and a community survey. Health Policy Plan. 33(1), e26-e33 (2014).

Azhar Z, Oyebode O, Masud H. Disrespect and abuse during childbirth in district Gujrat, Pakistan: A quest for respectful maternity care. Annals of Global Health. 83(1), (2017).

Ogunlaja A, Fehintola O, Ogunlaja I. "Respectful Maternity Care" or "Disrespect and Abuse during Maternity Care"; Experience of pregnant women in Ogbomoso, South West Nigeria. Rwanda Med. J. 74(3), 6-9 (2017).

Wassihun B, Zeleke S. Compassionate and respectful maternity care during facility-based childbirth and women's intent to use maternity service in Bahir Dar, Ethiopia. BMC Pregnancy and Childbirth. 18(1), 294 (2018).

Atai OP, Inyama H, Wakasiaka S, Jebet J, Oyieke J. Prevalence of disrespectful maternity care and abuse among women seeking maternity care services at the Kenyatta National Hospital, Nairobi: A cross-sectional descriptive study. OJOG. 8(06), 610 (2018). 